\title{
ВИЗНАЧЕННЯ ОСОБЛИВОСТЕЙ ГЕНОТИПІВ У ЖІНОК 3 ГЕНІТАЛЬНИМ ЕНДОМЕТРІОЗОМ ТА ФІБРОЗНО-КІСТОЗНОЮ МАСТОПАТІЄЮ ТА ЇХ РОЛЬ У ТЯЖКОСТІ ПЕРЕБІГУ ЗАХВОРЮВАННЯ
}

\author{
Л. М. Маланчук, В. М. Мартинюк \\ ДВНЗ «Тернопільський державний медичний університет \\ імені І. Я. Горбачевського МОЗ України»
}

\begin{abstract}
Наукова робота присвячена актуальній проблемі сучасності - дисгормональним захворюванням жіночої репродуктивної системи, а саме генітальному ендометріозу і фіброзно-кістозній мастопатії. Протягом останніх років спостерігається неухильне зростання поєднаної генітальної патології та захворювань молочних залоз. Згідно зі статистичними даними, частота дисгормональних захворювань молочних залоз у популяції жіночого населення, що страждають різними гінекологічними захворюваннями, коливається в межах 76-98 \%. Відомо, що ризик виникнення даної патології тісно пов'язаний з деякими алельними варіантами генів системи детоксикації, сім'ї глутатіон - S- трансферази і проонкогенними р 53, що характеризуються значним поліморфізмом. У статті представлені результати дослідження ролі делеційних варіантів генів GSTT1, GSTM1 і р 53 у розвитку ендометріозу і фіброзно-кістозної мастопатії. Скринінг популяцій на носійство таких алелей дозволяє виявити жінок, схильних до розвитку цих захворювань, і вибрати найефективнішу тактику медикаментозної терапії при виникненні даної патології.
\end{abstract}

Ключові слова: аденоміоз, фріброзно-кістозна мастопатія, гени GSTT1 і GSTM1 і р 53.

\section{ОПРЕДЕЛЕНИЕ ОСОБЕННОСТЕЙ ГЕНОТИПА У ЖЕНЩИН С ГЕНИТАЛЬНЫМ ЭНДОМЕТРИОЗОМ И ФИБРОЗНО-КИСТОЗНОЙ МАСТОПАТИЕЙ И ИХ РОЛЬ В ТЯЖЕСТИ ЗАБОЛЕВАНИЯ}

ГВУз «Тернопольской государственный медицинский университет имени И. Я. Горбачевского МЗ Украины»

\begin{abstract}
Научная работа посвящена актуальной проблеме современности - дисгормональным заболеванием женской репродуктивной системы, а именно генитальному эндометриозу и фиброзно-кистозной мастопатии. В течение последних лет наблюдается неуклонный рост сопряженной генитальной патологии и заболеваний молочных желез. Согласно статистическим данным, частота дисгормональных заболеваний молочных желез в популяции женского населения, страдающих различными гинекологическими заболеваниями, колеблется в пределах 76-98 \%. Известно, что риск возникновения данной патологии тесно связан с некоторыми аллельными вариантами генов системы детоксикации, семьи глутатион - S- трансферазы и проонкогеном р 53, характеризующихся значительным полиморфизмом. В статье представлены результаты исследования роли делеционных вариантов генов GSTT1, GSTM1 и р 53 в развитии эндометриоза и фриброзно-кистозной мастопатии. Скрининг популяций на носительство таких аллелей позволяет выявить женщин, склонных к развитию этих заболеваний, и выбирать наиболее эффективную тактику медикаментозной терапии при возникновении данной патологии.
\end{abstract}

Ключевые слова: аденомиоз, фиброзно-кистозная мастопатия, гены GSTT1 и GSTM1 и р 53.

\section{DETERMINATION OF GENOTYPE CHARACTERISTICS IN WOMEN WITH ENDOMETRIOSIS AND FIBROUS-CYSTIC MASTITIS AND THEIR ROLE IN DISEASE SEVERITY}

L. M. Malanchuk, V. M. Martinyuk

SHEI «Ternopil State Medical University by I. Ya. Horbachevsky of MPH of Ukraine»

The scientific work is devoted to the urgent problem of our time - dishormonal disease of the female reproductive system, namely endometriosis and fibrosis-cystic mastitis. During the last years there has been a steady increase in the dual

(C) Л. М. Маланчук, В. М. Мартинюк 


\section{МЕДИЧНА ІНФОРМАТИКА TA IHЖЕНЕРІЯ}

pathology of genital and breast diseases. According to statistics dishormonal frequency of breast diseases in the population of the female population suffering from various gynecological diseases varies between 76-98 \%. It is known that the risk of this disease is closely associated with some alleles detoxification system, glutathione family - S- transferase and proonkogenom p 53, characterized by significant polymorphism. The article presents the results of research on the role of deletion variants of genes GSTT1, GSTM1 and p 53 in the development of endometriosis and fibrosis-cystic mastitis. Screening populations on carriage of alleles reveals women who are likely to develop these diseases and choose the most effective tactics of medical treatment in the event of the disease.

Key words: adenomyosis, fibro-cystic breast disease, genes: GSTT1 and GSTM1 and p 53.

Генітальний ендометріоз залишається однією 3 найактуальніших проблем клінічної медицини, що пов'язано з його високою поширеністю, несвоєчасною діагностикою, недостатньо ефективним лікуванням та несприятливим прогнозом. У структурі гінекологічної захворюваності він займає 3 місце після запальних захворювань жіночих геніталій і лейоміоми матки $[4,6]$. Згідно з даними світової літератури, у країнах Європи ендометріоз зустрічається майже в $10 \%$ жінок, а в Україні його частота у жінок фертильного віку коливається від 7 до 50 \%. Висунуті численні теорії виникнення ендометріозу, які до кінця не пояснюють природу цієї патології. В останні роки з'явились наукові роботи, які свідчать на користь того, що в генезі генітального ендометріозу (ГЕ) важливу роль відіграють гени метаболізму, які характеризуються великою варіабельністю молекулярної структури ДНК $[1,2,8]$. Поліморфізм генів детоксикації дуже часто суттєво впливає на їх функціональну активність. Більшість поліморфних варіантів цих генів асоціюється з розвитком різних мультифакторіальних захворювань, в тому числі і ендометріозу. Не викликає сумніву, що несприятливі фактори зовнішнього середовища в поєднанні із «ослабленим» генотипом можуть бути однією із причин розвитку даного захворювання [3, 5, 7].

Протягом останніх років спостерігається тенденція до зростання генітальної патології та захворювань молочних залоз. Згідно з статистичними даними, частота дисгормональних захворювань молочних залоз у популяції жіночого населення коливається в межах від 14 до 42 \%, а у жінок, що страждають різними гінекологічними захворюваннями - 76 - 98 \%. Адже фізіологічні процеси, що відбуваються в молочних залозах, тісно пов'язані із циклічними змінами в репродуктивній системі. Це дає можливість припустити високу ймовірність виникнення патологічних змін у молочних залозах при різних гінекологічних захворюваннях, які розвиваються в результаті порушень гіпоталамогіпофізарно-яєчникової системи.
Метою нашого дослідження було визначення особливостей генотипів у жінок 3 генітальним ендометріозом та фіброзно-кістозною мастопатією та їх ролі у тяжкості перебігу захворювання.

Матеріали і методи. Клінічна частина роботи виконувалась на базі відділення ТОКПЦ «Мати і дитина», лабораторна діагностика - в Міжкафедральній науково-клінічній лабораторії ДВНЗ «Тернопільський державний медичний університет ім. І. Я. Горбачевського МОЗ України». Обстежено 20 пацієнток 3 генітальним ендометріозом i патологією молочних залоз (основна група) та 20 жінок 3 генітальним ендометріозом (група порівняння) віком від 27 до 45 років. Контрольна група була сформована із 20 жінок, при обстеженні яких генітальний ендометріоз був виключений, а також без клінічних проявів оваріо-менструальної дисфункції. У всіх пацієнток було отримано добровільну інформовану згоду на забір венозної крові і використання її для проведення дослідження. Для проведення медико-генетичного дослідження відбиралось 3-5 мл венозної крові, яку брали із v. сиьіїа^ в стандартних умовах вранці, натщесерце в спеціальну вакуумну систему - 3 \% EDTA. Після взяття крові пробірку декілька разів перевертали вверх дном, для змішування крові із антикоагулянтом.

Наяскравішим клінічним проявом ендометріозу $\epsilon$ больовий синдром, який пов'язаний із менструальним циклом: тягнучі болі внизу живота 3 іррадіацією в поперекову ділянку, які підсилюються напередодні менструацій, та болючі менструації. В таблиці 1 представлені частота та характер больового синдрому у пацієнток досліджуваних груп.

Для оцінки вираженості больового синдрому використовували шкалу Mac Laverty C.M., Shaw R.W. (1995), яка виділяє три ступені тяжкості больового індексу (за сумою балів): легкий - до 3 балів, середній - 4-6 балів, тяжкий - 7-9 балів. Таким чином, у 25 \% обстежених пацієнток I групи та у $40 \%$ II групи відмічено легкий ступінь больового синдрому. Середній ступінь тяжкості спостерігали у 75 \% 
Таблиця 1. Частота і характер больового синдрому у досліджуваних групах пацієнток

\begin{tabular}{|c|c|c|}
\hline \multirow{2}{*}{ Характеристика больового синдрому } & Аденоміоз та ФКМ & Аденоміоз \\
\hline & $\mathrm{n}=20$ & $\mathrm{n}=20$ \\
\hline Болі в нижніх відділах живота & $18(90 \%)$ & $15(30 \%)$ \\
\hline Іррадіація болю в поперекову ділянку і пряму кишку & $12(60 \%)$ & $10(60 \%)$ \\
\hline Біль під час статевого акту & $6(30 \%)$ & $6(30 \%)$ \\
\hline
\end{tabular}

жінок I та 40 \% II досліджуваних груп. Масталгія була діагностована майже у всіх пацієнток I групи (95\%) і лише в 1/3 хворих II групи.

Окрім вираженості больового синдрому, особливу увагу приділяли вивченню особливостей менструальної функції в обох досліджуваних групах.

У таблиці 2 представлена характеристика порушень менструального циклу в обстежуваних жінок.

Таблиця 2. Характеристика порушень менструального циклу у досліджуваних пацієнток

\begin{tabular}{|l|c|c|}
\hline \multirow{2}{*}{ Порушення менструального циклу } & Аденоміоз та ФКМ & Аденоміоз \\
\cline { 2 - 3 } & $\mathrm{n}=20$ & $\mathrm{n}=20$ \\
\hline Тяжкі менструальні кровотечі & $8(40 \%)$ & $12(60 \%)$ \\
\hline Мажучі передменструальні виділення & $15(75 \%)$ & $16(80 \%)$ \\
\hline Дисменорея & $18(90 \%)$ & $12 \%)$ \\
\hline
\end{tabular}

Відмічено, що у жінок з аденоміозом та фібрознокістозною мастопатією достовірно частіше були прояви менструальної дисфункції.

Проаналізувавши спадковий анамнез пацієнток основної та групи порівняння, було виявлено, що у $85 \%$ I групи та у $65 \%$ жінок II групи були різні види гінекологічної патології у родичів першої лінії (рис. 1).

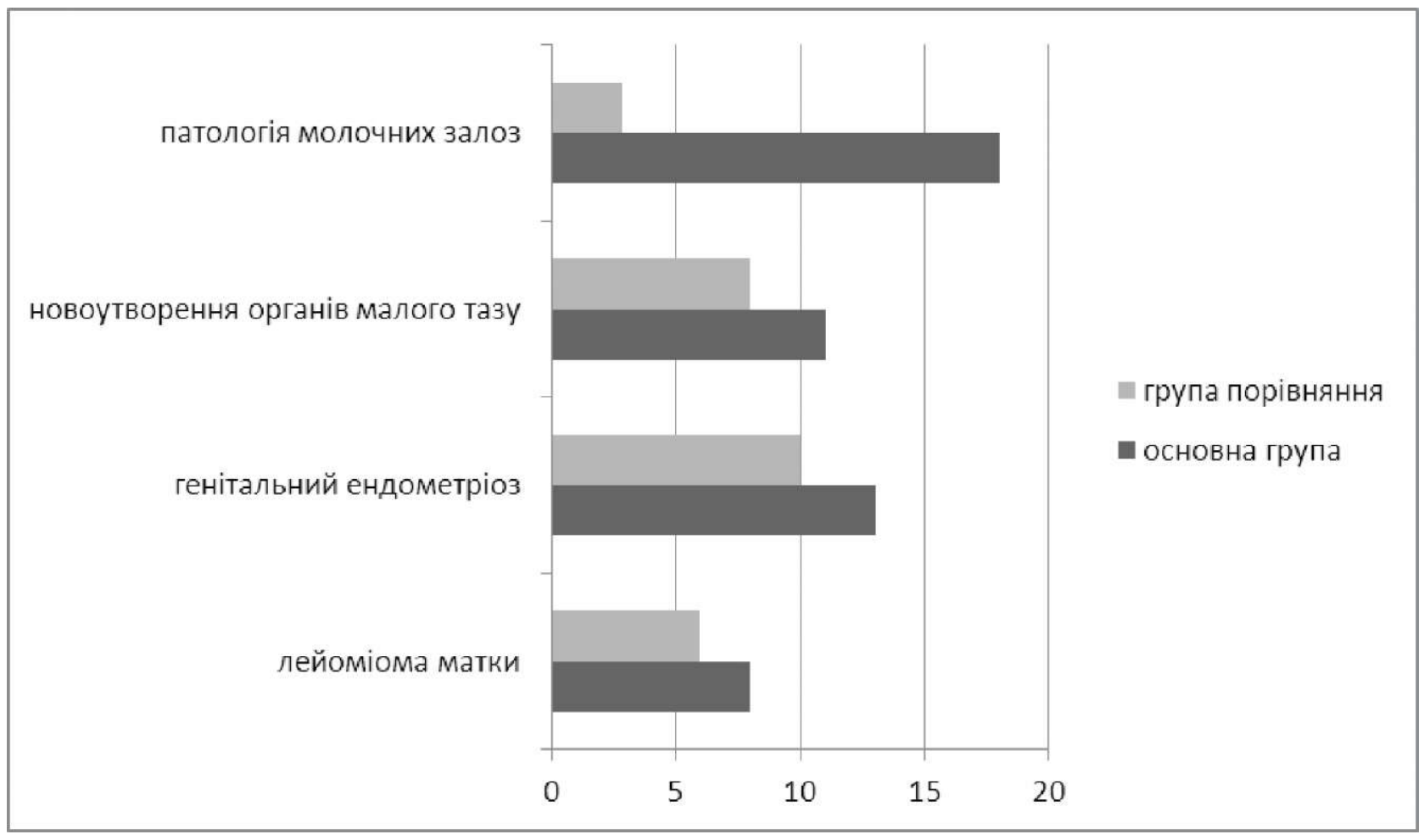

Puc. 1. Спадковий анамнез пацієнток досліджуваних груп 


\section{МЕДИЧНА ІНФОРМАТИКА TA IHЖЕНЕРІЯ}

Методом полімеразної ланцюгової реакції досліджено частоти поліморфних варіантів генів GSTM1 та GSTT1. Виділення ДНК із периферійної крові проводили за допомогою тест-системи «АмпліСенс» (Росія), відповідно до інструкції, що додається. Ідентифікація інерційно-делеційного поліморфізму в генах GSTT1 та GSTM1 (глутатіон - S- трансфераз класу Т1 і М1) проводили методом ПЛР, ЛПБ «NEOGEN», Київ. Гомозигот і гетерозигот за нормальним алелем «+» генів GSTT1 та GSTM1 визначали на електрофореграмах за наявністю смуги на рівні 218 п. о. (GSTM1) і 460 п. о. (GSTT1). Відсутність відповідних смуг вказувала на гомозиготність індивідума за делеціями двох генів.

Таблиця 3. Розподіл генотипів GSTM1 та GSTT1 генів в групі хворих з ендометріозом та в групі контролю

\begin{tabular}{|l|c|c|c|c|}
\hline \multirow{2}{*}{ Ген } & \multirow{2}{*}{ Генотип } & Аденоміоз та ФКМ & Аденоміоз & Контроль \\
\cline { 2 - 5 } & & $\mathrm{n}=20$ & $\mathrm{n}=20$ & $\mathrm{n}=20$ \\
\hline \multirow{3}{*}{ GSTM1 } & $0 / 0$ & $11(55 \%)$ & $10(50 \%)$ & $9(45 \%)$ \\
\cline { 2 - 5 } & $+/+$ & $9(45 \%)$ & $10(50 \%)$ & $11(55 \%)$ \\
\hline \multirow{3}{*}{ GSTT1 } & $0 / 0$ & $14(70 \%)$ & $12(60 \%)$ & $5(25 \%)$ \\
\hline \multirow{3}{*}{ P 53 } & $+/+$ & $1(5 \%)$ & $8(40 \%)$ & $15(75 \%)$ \\
\cline { 2 - 5 } & ins/ins & $3(15 \%)$ & - & - \\
\cline { 2 - 5 } & ins/del & $16(80 \%)$ & $19(95 \%)$ & $20(100 \%)$ \\
\hline
\end{tabular}

Результати та їх обговорення. В результаті проведеного аналізу поліморфних варіантів гена GSTM1 не виявлено статистично достовірних різниць в частотах мутації цього гена у пацієнток I, II та контрольної груп (55\%, 50 \% і 45 \% відповідно). Частота гомозигот за нульовим алелем GSTT1 виявилась вищою у жінок основної та групи порівняння, ніж у контролі (70\%, 60 \% i $25 \%$ відповідно).

Ми проаналізували розподіл поєднань генотипів відразу за двома генами глутатіон^^-трансфераз в I групі жінок, групі пацієнток з аденоміозом та в групі контролю. Слід зауважити, що делеції в обох генах GSTM1 та GSTT1, порівняно з іншими генотипами, зустрічались достовірно частіше у пацієнток I та II досліджуваних груп, ніж у контролі.

При аналізі ins / del поліморфізму гена p 53 було виявлено, що у пацієнток $з$ аденоміозом та фіброзно-кістозною мастопатією частота генотипу ins / del зустрічалась в 36 разів частіше, а ніж в групі порівняння (15\% і 5 \% відповідно). В групі контролю даний генотип не спостерігали в жодному випадку. Цікаво, що генотип ins/ins не виявлено у жінок з аденоміозом та в групі контролю, він був виявлений лише в основній групі пацієнток.

Висновки. Протягом останніх років проблема доброякісних захворювань матки та молочних залоз, а також їх поєднання, набула особливої актуальності, що обумовлено зростанням частоти даної патології та порушенням генеративної функції жінки. На жаль, етіологія ендометріозу на сьогоднішній день залишається не з'ясованою. Не викликає сумніву, що в генезі цього захворювання важливу роль відіграють гени метаболізму та проонкогени.

В результаті проведеного аналізу поліморфних варіантів гена GSTM1 ми не виявили статистично достовірних різниць в частотах делецій цього гена у пацієнток основної групи, групи порівняння та групи контролю $(55 \%, 50 \%$ і 45 \% відповідно). Частота гомозигот за нульовим алелем GSTT1 виявилась вищою у жінок I та II груп, ніж в контролі (70\%, $60 \%$ і $25 \%$ відповідно). Проаналізувавши розподіл поєднань генотипів відразу за двома генами системи детоксикації, GSTM1 та GSTT1, ми відмітили, що делеції в обох генах глутатіон $\mathrm{S}$ - трансфераз зустрічались достовірно частіше в жінок I та II груп, ніж в групі контролю.

Оскільки аденоміоз належить до захворювань пухлинної природи, великий інтерес викликало вивчення поліморфних варіантів генів, що забезпечують екстрене видалення пошкоджених i потенційно небезпечних клітин, а саме ген р 53. При аналізі частот двох поліморфних варіантів $p$ 53 ins / del ми виявили, що у пацієнток основної групи частота генотипу ins / del спостерігалась в 3 випадках, ins / ins - в 1, a del/del - в 16 жінок.

Подальші дослідження генетичних аспектів аденоміозу та патології молочних залоз, вивчення окремих поєднань конкретних алелей генів «схиль- 
ності» до цих поширених гінекологічних захворювань матиме важливе значення для розробки нових

\section{Література}

1. Голубева О. В. Клинико-генетический анализ генитального эндометриоза: эндометриомы яичников и аденомиоза : автореф. дис. на соискание науч. степени канд. мед. наук / О. В. Голубева. - М., 2007. - 24 с.

2. Генетические факторы предрасположенности к аденомиозу / О. В. Голубева, Т. Э. Иващенко, В. С. Баранов, 3. К. Айламазян // Журнал акушерства и женских болезней. - 2007. - T. LVI, № 2. - С. 25-39.

3. Запорожан В. М. Генетична схильність до ендометріозу: від теоретичних моделей до практичного генетичного моніторингу / В. М. Запорожан, О. В. Михайленко // Одеський медичний журнал. - 2009. - № 2 (112). C. 46-48.

4. Лобанова О. Т. Генетические и иммунологические аспекты внутреннего эндометриоза : автореф. дисс. на соискание научной степени канд. мед. наук: спец. 14. 01. 01 M., 2003. - 22 c. методів лікування 3 врахуванням індивідуальних особливостей геному.

5. Рожковска Н. М. Генетичні поліморфізми та функціональний стан рецепторного апарату ендометрія при ендометріозі / Наталія Рожковська, Кристина Кротенко // Педіатрія, акушерство та гінекологія. - 2012. - Т. 74, № 1. - C. 97-99

6. Adenomyosis: epidemiological factors. / P. Vercellini, P. Vigano, E. Somigliana // Best Pract Res Clin Obstet Gynaecol. - 2006. - Vol. 20 ( 4 ) - P. 465 - 477.

7. Glutathione-S-transferase PI gene polymorphism and susceptibility to endometriosis / D. Ertunc, M. Aban, E. С. Ток $^{\wedge}$ al.] // Hum Reprod. - 2005. № 20(8). P. 2157-2161.

8. McLeod B. S. Epidemiology of endometriosis: an assessment of risk factors / B. S. McLeod, M. G. Retzloff // Clin. Obstet. Gynecol. - 2010 - Vol. 53 (2) - P. 389-396. 